\title{
A Review of Transnational Regulations
}

\section{in Environmental Protection and the Circular Economy}

\author{
Zofia Wysokińska \\ Ph.D., Full Professor at the University of Lodz, Faculty of Economics and Sociology \\ Department of World Economy and European Integration, Lodz, Poland \\ e-mail: zofia.wysokinska@uni.lodz.pl
}

\section{Abstract}

The aim of the paper is to present a review of transnational regulations (global and European) in the field of environmental protection and the circular economy. The paper discusses the regulations proposed in publications and reports of such global organizations and UN Agencies as the United Nations Environmental Program (UNEP), the United Nations Conference for Trade and Development (UNCTAD), the Food and Agriculture Organization (FAO), as well as the World Trade Organization (WTO), and the European Commission as the Executive Body of the European Union. With regard to the WTO, these regulations concern the effects of liberalizing trade in environmental goods and services and environmentally sound technologies. Sustainable development means, above all, protecting the natural environment and reducing excessive dependence on depleting natural resources, including primary raw materials, in the economic sector. This implies the need to implement a new resource-efficient development model, based on the principles of the circular economy (CE), which has been proposed for several years by transnational organizations. In the CE model, the use of natural resources is minimized, and when a product reaches the end of its useful life, it is reused to create additional new value. This can bring significant economic benefits, contributing to new production methods and new innovative products, growth, and job creation.

The topics mentioned above are the main subject of consideration in the presented paper.

Keywords: transnational and European regulations, environmental protection, circular economy, global organizations, European Union

JEL: 013 


\section{Introduction}

Sustainable development, as well as the protection and preservation of the environment, are the objectives of all global, international and regional organizations, with particular reference to the WTO (World Trade Organization), United Nations (UN) bodies such as UNEP (United Nations Environmental Program), UNCTAD (United Nations Conference for Trade and Development), or UNIDO (United Nations Industrial Development Organizations), and the FAO (Food and Agriculture Organization). Among the international regional groupings, the European Union plays an extremely active role, especially in promoting rules and regulations regarding the implementation of the circular economy.

\section{The role of the WTO and United Nations Bodies}

The WTO plays a special role in promoting the liberalization of foreign trade in environmentally friendly products and services and environmentally sound technologies. These aspects are enshrined in the Marrakesh Agreement, which established the WTO in 1994. And alongside the main WTO goal of reducing trade barriers and eliminating discriminatory treatment in international trade relations, they constitute a complementary goal which, in recent years, together with the pursuit of ambitious Sustainable Development Goals (SDGs), has become particularly important (Trade and environment).

Both the WTO and the United Nations Environmental Program (UNEP) strengthen international dialogue on trade and environmental issues. Environmental management is now a key driver for achieving sustainable development. In a globalized world, environmental threats require effective responses that promote the highest values, such as peace, justice, development, and compliance with environmental principles and human rights.

The UN promotes environmental management - including principles, policies, and institutions that shape people's interactions with the environment. Building stable management systems makes it possible to protect the environment and human rights and achieve all 17 UN sustainable development goals by 2030 (Sustainable Development Goals; Environmental rights and governance overview; see also: Wysokińska 2017).

UNEP's activities include helping governments obtain environmental information to make decisions and provide citizens with greater access to information on their environmental rights; strengthening environmental cooperation at global and regional levels, and promoting the relationship between civil society and governments in the development and implementation of environmental policies.

Identifying common goals in international environmental agreements and actions for dialogue on environmental issues at a regional level is also helpful. UNEP, through the environmental sub-program, deals with the most important factors that enable the achievement of progress in achieving these goals, i.e., in particular, those related 
to the integration of environmental sustainability in development at regional, subregional, and national levels (Environmental rights and governance).

The updated program of partnership cooperation between UNEP and UN bodies, international organizations, and UNEP member states was agreed in August 2019. This Program contributes to the advancement of sound environmental governance in one of the following ways (Environmental Governance Update... 2019):

- UN bodies and international organizations integrate environmental policy issues from UNEP policy advice;

- The uptake of approaches for the coherent implementation of multiple multilateral environmental agreements;

- Policy action is taken by countries on environmental issues of international concern;

- Countries with enhanced institutional capacity and legal frameworks fully implement international environmental objectives;

- Increased integration of the environment in sustainable development planning;

- Increased partnerships between UNEP and stakeholders to promote the achievement of internationally agreed environmental goals.

UNEP cooperates with governments and relevant institutions in the UN system, such as UNCTAD, FAO, and UNIDO, through the environmental management sub-program, as well as with the WTO within the framework of Multilateral Environmental Agreements (MEAs), to promote more consistent, effective, and efficient decision-making and action for environmental protection and to mitigate adverse climate changes.

InforMEA is the United Nations Information Portal on Multilateral Environmental Agreements, an online portal that provides information about the MEAs to the public. The InforMEA Initiative consists of $20 \mathrm{MEAs}$ hosted with four United Nations bodies. The MEAs include Basel, Rotterdam, Stockholm, and Minamata (Chemicals and Wastes); CBD (Biodiversity); CITES (Trade in Wildlife); ITPR-FA (Plants); Vienna (Ozone); Ramsar (Wetlands); UNESCO-WHC (World Heritage); UNCCD (Deserts); UNFCCC (United Nations Framework Convention on Climate Change); as well as 5 UNECE (United Nations Economic Commission for Europe) Conventions and a number of regional conventions (UNESCO 2011).

Multilateral Environmental Agreements. The Agreement signed in 1997 resulted from the need for common regulations in the field of environmental protection. MEAs are based on MEA-s are based on the general principles of cooperation with ISO (International Organization for Standardization).

The four main MEAs Systems include:

- CITES - the Convention on International Trade in Endangered Species of Wild Fauna and Flora. The main goal of this convention is to ensure the inviolability of wild fauna and flora, i.e., the member states' commitment that fauna and flora cannot be exploited as a result of the development of international trade.

- The Montreal Protocol on Substances that Deplete the Ozone Layer is an international agreement made in 1987. It was designed to stop the production and 
import of ozone depleting substances and reduce their concentration in the atmosphere to help protect the earth's ozone layer. The Montreal Protocol sits under the Vienna Convention for the Protection of the Ozone Layer. The Vienna Convention was adopted in 1985 following international discussion of scientific discoveries in the 1970s and 1980s highlighting the adverse effect of human activity on ozone levels in the stratosphere and the discovery of the 'ozone hole'. Its objectives are to promote cooperation on the adverse effects of human activities on the ozone layer. The Montreal Protocol was agreed on 16 September 1987 and entered into force on 16 September 1989, following a first meeting in Helsinki, May 1989. Since then, it has undergone eight revisions, in 1990 (London), 1991 (Nairobi), 1992 (Copenhagen), 1993 (Bangkok), 1995 (Vienna), 1997 (Montreal), 1998 (Australia), 1999 (Beijing), and 2016 (Kigali - which was adopted but has not come into force).

- As a result of the international agreement, the ozone hole in Antarctica is slowly recovering. Climate projections indicate that the ozone layer will return to 1980 levels between 2050 and 2070.

- The Basel Convention on the Control of Transboundary Movements of Hazardous Wastes and their Disposal was adopted on 22 March 1989 by the Conference of Plenipotentiaries in Basel (Switzerland) in response to a public outcry following the discovery in the 1980s of deposits of toxic wastes imported from abroad in Africa and other parts of the developing world.

- The Stockholm Convention on Persistent Organic Pollutants is an international environmental treaty, signed in 2001 and effective from May 2004, that aims to eliminate or restrict the production and use of persistent organic pollutants (POPs).

UNIDO supports countries in their environmental management efforts, including the implementation of multilateral environmental agreements and the provision of sustainable energy. It helps create new green industries, establishing national road maps for greening the supply chain, determining benchmarks and indicators, disseminating and sharing best practices, running clean technology programs, undertaking various capacity-building exercises, and contributing to international forums with the necessary research and expertise.

UNIDO's services include capacity building, direct technical support to enterprises, and assistance to government institutions on Cleaner Production (CP) policy matters, as well as the promotion, adaptation, and transfer of environmentally sound technologies and the implementation of advanced CP business models, such as chemical leasing.

In the field of water management, UNIDO focuses on the sustainable use of water resources. This includes capacity-building for the industrial sector to improve water productivity, reuse, and recycling, as well as the introduction at all levels of government policies and training in the adoption of the ecosystem approach and the sustainable use of its living resources. 
UNIDO stresses the need to improve industrial energy efficiency by contributing to the transformation of markets for energy-efficient products and services. It promotes sustainable energy solutions for making industries more productive and climate-resilient, which in turn promotes green jobs and green growth, including the deployment of industrial energy efficiency standards, smart grids based on renewable energy, and renewable energy for industrial applications, as well as the promotion of climate-resilient industries. An urgent need also remains to phase out the production and consumption of ozone-depleting substances (ODSs), which lead to the continuing degradation of human health and the natural environment. The Vienna Convention and the Montreal Protocol respond to that need.

UNIDO assists the governments of developing countries that are signatories to the Montreal Protocol to comply with its requirements through transferring non-ODS-based technologies to Article 5 countries and supports them to meet the set targets in terms of tonnages of ODS to be eliminated. There is a commitment on the part of governments that are parties to the Stockholm Convention on Persistent Organic Pollutants (POPs) to implement legal, organizational, and environmental management measures, including substantive technological changes, in order to comply with the requirements of the Convention. The production and use of POPs, as well as their presence in the biosphere, are causing severe damage to human health and the environment. UNIDO also assist countries in reaching compliance with the Stockholm Convention and develops capacity in developing countries to protect their populations and their environmental resources from POP-related pollution. UNIDO also supports countries in addressing the commitments under the Minamata Convention on Mercury. UNIDO also supports countries in building capacity to plan, develop, and implement related industrial development aspects in the United Nations Framework Convention on Climate Change (UNFCCC) (Implementation of multilateral environmental agreements).

Most international financial institutions (IFIs) require collateral to approve various types of development projects. Environmental security (as well as social security) are the cornerstones of IFIs' support for sustainable development. The purpose of these policies is to avoid or, where avoidance is not possible, to minimize and mitigate the negative impact of the project on the environment and people affected by this problem, as well as to help borrowers (and grant beneficiaries) strengthen their security systems and develop their capacity to manage the environmental risks. The key environmental issues include biodiversity protection, sustainable management of natural resources, pollution prevention and reduction, use of pesticides, and greenhouse gas emissions. Security principles provide guidelines for international financial institutions and borrower/country personnel in identifying, preparing, and implementing programs and projects. They also provide a mechanism for incorporating environmental issues into the development decision-making process (The Food and Agriculture Organization). 


\section{Regulations concerning trade in environmental goods under the WTO, and Bio-Trade under the UNCTAD BioTrade Initiative}

The negotiations within the WTO on the agreement on trade in environmental goods (Environmental Goods Agreement - EGA) began on 8 July 2014.

The parties negotiating the agreement were 18 WTO members, including the USA, EU, China, Canada, and Japan. The purpose of this initiative was to facilitate international trade in environmentally friendly goods and technologies. During the negotiations, the parties sought to eliminate or reduce tariffs on goods that would be identified as key to environmental protection and, for example, to clean water and air, or that would measure pollution, produce energy from renewable sources, etc. As a result of the negative attitude of the US administration, the talks were suspended. They were later continued in 2016-2017 (Environmental Goods Agreement...).

The second phase of the negotiations mainly concerned products that can help achieve environmental and climate protection goals, such as generating clean and renewable energy, improving energy and resource efficiency, controlling air pollution, managing waste, treating wastewater, monitoring the quality of the environment, and combatting noise pollution.

The participants to these negotiations account for the majority of global trade in environmental goods. The benefits of this new agreement will be extended to the entire WTO membership, meaning all WTO members will enjoy improved conditions in the markets of the participants to the EGA. The participants in these negotiations were 18 Partners representing 46 WTO members, i.e., Australia, Canada, China, Costa Rica, the European Union, Hong Kong China, Iceland, Israel, Japan, Korea, New Zealand, Norway, Singapore, Switzerland, Liechtenstein, Chinese Taipei, Turkey, and the United States (Environmental Goods Agreement news archive).

Environmentally sound technologies $(E S T)^{1}$, often also referred to as "clean" technologies, are technologies that reduce the risk to the environment and minimize pollu-

1 ESTs are technologies that "protect the environment, are less polluting, use all resources in a more sustainable way, process more of their waste and products and process residual waste in a more acceptable way than the technologies they replaced" (Agenda 21). They are not just individual technologies, but complete systems that include know-how, procedures, goods and services, and equipment, as well as organizational and management procedures to promote environmental sustainability. Closely related to ESTs is the concept of goods and services related to environmental protection, which is more widely used in trade negotiations and discussions. To date, there is no precise definition of goods and services related to environmental protection, and some WTO members have tried to solve this problem by listing products that interest them. They are generally divided into six categories, namely air pollution control, renewable energy, waste management and water treatment, environmental technologies (i.e., emissions reduction, heat and energy management, environmental monitoring equipment), carbon capture and storage, and other areas that may be related to the removal of waste, and the protection of natural resources, etc., based on United Nations Environment Program 2018, pp. 3-4. 
tion as well as the consumption of energy and resources, and they are necessary in the fight against climate change. They also contribute to the achievement of many sustainable development goals, such as goal 7 concerning energy, goal 8 related to growth, goal 12 regarding sustainable consumption and production, and goal 13 - actions dedicated to the climate.

Trade liberalization can further facilitate market creation and the expansion of ESTs and create opportunities for enterprises, particularly in developing countries, to participate in regional and global value chains. Increasing EST trade can give a triple victory by promoting economic development, industrialization, job creation, and innovation while giving countries more efficient access to the technologies needed to improve their environmental performance.

It should be noted that trade in environmentally sound technologies is steadily increasing with the growing participation of developing countries. Despite a slight decrease in trade flows since reaching the maximum in 2011, global trade in EST-related goods has shown a steady upward trend since 2006. However, a significant proportion of the EST industry is still concentrated in a relatively small number of countries. As for the larger EST group, trade in selected ESTs is still dominated by developed countries and emerging economies. The main exporters of selected ESTs between 2006 and 2016 were China, Germany, the United States, Japan, and Korea. The leading traders among developing countries were Mexico, Malaysia, and South Africa. New Caledonia, Senegal, Uganda, and Ethiopia are among the least developed countries, although they export the most. Solar photovoltaic modules, wafers, and cells are the most frequently sold ESTs with a clear environmental end-use. The overall growth rates of EST trade have been unstable since the global financial crisis in 2009, especially for the least-developed countries, and they peaked in 2010. Between 2006 and 2016, the share of developing countries and BRIC countries in global trade in EST goods neared the overall trade surplus.

Analysis of trade in EST-related services shows that the value of trade in this sector increased more than five times over the past decade. Data from the 61 largest companies that have the largest share in terms of trade value in environmental consulting and engineering services show that revenues are mainly concentrated in North America and Europe (United Nations Environment Program 2018, pp. 2-3).

The global trade in EST increased by over 60\% from USD 0.9 trillion in 2006 to USD 1.4 trillion in $2016^{2}$, with renewable energy technologies accounting for over a third

2 Comparative research on the development of the global and European market in the first decade of the new century showed that the environmental goods and services market was among those world markets that has demonstrated one of the highest growth rates in demand over the past ten years in the period 2000-2010. Its volume was assessed at approximately USD 518 billion in the year 2000 and projections for the year 2010 assume its growth to approximately 600 billion (Environment Business International, Inc., in Environmental Benefits of Removing Trade Restrictions and Distortions, Note by the Secretariat, Addendum, Committee on Trade and Environment. WT/ CTE/W/67/ADD.1, March 13, 1998; "Implications of WTO Agreements for International Trade in Environmental Industries," ITC, 1999, in Trade and Environment Review 2003, United Nations, 
of total trade, followed by wastewater and water treatment and solid and hazardous waste management technologies (United Nations Environment Programme 2018, p. 2). While emerging economies such as China have dramatically increased their share of global EST trade, many low-income countries, especially the least developed countries (LDCs), have not yet fully benefited from EST trade.

Negotiations in EST trade have made progress at the international and regional levels. Following early discussions in the context of Asia-Pacific (APEC) and WTO economic cooperation, smaller groups of countries have made recent efforts to negotiate an environmental goods agreement (EGA) to lift tariffs on selected environmental goods (United Nations Environment Programme 2018, pp. 7-8).

The negotiations on the Trade in Services Agreement (TiSA) were launched in 2013. Several negotiating parties submitted proposals for further opening of environmental services markets and insisted on ambitious commitments. However, progress in reaching an agreement has stalled.

A notable initiative at the regional level is the APEC Agreement on Environmental Goods, which aims to voluntarily reduce the tariffs applied for 54 categories of organic products to no more than $5 \%$. The agreement represents by far the most specific commitments to trade liberalization associated with organic goods among a large group of trading partners (United Nations Environment Programme 2018, p. 4).

Geneva, New York, 2004; The research carried out at the Department of World Economy and European Integration at the University of Lodz, showed that the low and irregular share of foreign trade in environmental services and world export in environmental services over various years is at a level of barely $0.3-0.4 \%$ of what is produced. For comparison, world exports in environmental products is approximately $20 \%$ of their production. This shows a high disproportion in the trading of environmental products between its products and services sections. The environmental industry (i.e., industry "working" for environmental protection) was characterized by an average growth rate of more than $10 \%$ over the past ten to fifteen years. However, the dynamics of its growth in highly developed countries had a significantly lower rate, which barely amounted to approximately $1.6-2 \%$. At the same time, the growth rate in developing countries was at a level of approximately $7-8 \%$. Projections show that such growth will be particularly characteristic of those countries and will amount to approximately $8-12 \%$. Compared with other markets, it may be stated that the environmental products and services market is not as large as the steel or agricultural markets. However, its size is comparable with the pharmaceutical or information technology markets. The environmental products market encompasses three main segments-equipment (technical equipment), environmental services, and natural resources. Technical equipment obviously encompasses the most advanced technologies, while environmental services include simpler, albeit more common ones. The predicted growth of more than $15 \%$ in the sales of environmental services over the past decade is an additional approximately USD 42 billion increase in demand on the world market providing employment for approximately 1-2 million workers. It is the highly developed countries that are the largest producers of environmental services (United States - approximately $38 \%$ of the world market, Japan - approximately $18 \%$, and Germany, Great Britain, France, and Italy). A mere 2\%, approximately, make up the share of Eastern Europe (inclusive of the European part of the CIS), where Poland's share is between $0.3 \%$ and $0.4 \%$, based on Wysokińska 2009; see also: Wysokińska 2005, p. 25, see also: Wysokińska 2011, pp. 155-164. 


\section{Trade, Environment, Climate Change, and Sustainable Development - the role of UNCTAD}

UNCTAD's work on harnessing international trade in promoting sustained growth and inclusive development includes as a key aspect the support to developing countries in taking advantage of emerging opportunities for trade associated with the protection, promotion, and preservation of the environment and sustainable development objectives generally while minimizing potential adverse impacts. This work is carried out by the Trade, Environment, Climate Change, and Sustainable Development Branch of Division on International Trade and Commodities (DICT) of UNCTAD.

Through research and analysis, intergovernmental deliberations and consensus building, and technical assistance, as well as partnerships and networks with an array of stakeholders, the branch works to strengthen the capacity of developing countries to formulate and implement mutually supportive trade, environment, and sustainable development objectives; integrate sustainable development and poverty reduction objectives in development strategies at all levels, including the need to address climate change implications inter alia by promoting climate-friendly trade and production strategies, including in green sectors, and support the effective participation of developing countries in international deliberations on trade and environment $^{3}$.

\section{Developing countries have great potential to benefit from EST trade and global value chains}

EST trade offers developing countries great opportunities in terms of economic growth, diversification of exports, technological development, and environmental protection. In particular, environmental services, due to their local nature, provide enterprises in developing countries with the opportunity to join global value chains. EST trade and absorption of such technologies can additionally create sustainable jobs, especially in services related to the installation and maintenance of products, systems, and infrastructure related to environmental protection.

\section{BioTrade Initiative}

BioTrade (UNCTAD, BioTrade) refers to those activities of collection, production, transformation, and commercialization of goods and services derived from native biodiversity under the criteria of environmental, social, and economic sustainability.

3 Local Content Requirements and the Green Economy, Division of International Trade and Commodities-DITC; United Nations, 2014, https://unctad.org/system/files/official document/ditcted2013d7 en.pdf - data dostępu: 28.10.2018. 
Since its launch by UNCTAD in 1996, the BioTrade Initiative has been promoting sustainable BioTrade in support of the objectives of the Convention on Biological Diversity. The Initiative has developed a unique portfolio of regional and country programs.

UNCTAD is currently implementing the Global BioTrade Program: Linking trade, biodiversity, and sustainable development with the support of the Swiss State Secretariat for Economic Affairs (SECO). The objective of this four-year program is to provide key stakeholders with the ability to seize and capitalize on trade opportunities from linking biodiversity and sustainable development, thereby advancing the implementation of the SDGs, as well as the Aichi Targets and the Post Aichi framework (The next 20 years: Upscaling BioTrade and the 2030 Agenda).

In the past 20 years, BioTrade has expanded in terms of the number of partners and practitioners involved, sectors, and geographical coverage. BioTrade has been mainstreamed at both national and international levels, for instance, in the Decisions of the Parties to the CBD (Convention on Biological Diversity) and CITES (Convention on International Trade in Endangered Species of Wild Fauna and Flora), discussions at the United Nations General Assembly, as well as within development banks, the private sector, civil society, and markets. A strong network of partners and practitioners has been established and is being expanded continuously to cover the evolving needs of beneficiaries, document lessons learned, and address relevant emerging issues. Further efforts from BioTrade partners should continue documenting, disseminating, and measuring its impact and contribution to sustainable development, SDGs, and the Aichi Targets at all levels.

The BioTrade Initiative of UNCTAD facilitates and supports national, regional, and international BioTrade programs, partnerships, and businesses that have contributed to fighting biodiversity loss while ensuring the sustainable use of biological resources and ecosystems. Activities are implemented in close cooperation with the secretariats of the Convention on Biological Diversity and the Convention on International Trade in Endangered Species of Wild Fauna and Flora on the development of regulatory and institutional frameworks to prevent illicit trade in natural species and to safeguard them.

The main objective of the Bio-Trade Initiative is to build sustainable livelihoods, particularly for rural communities and marginalized groups, in biodiversity-rich developing countries. This is central to the conservation and sustainable use of nature's resources. Thus, UNCTAD collaborates with Governments, the private sector and international organizations in all countries to promote BioTrade-programs and businesses that adhere to sustainable development principles, ethical sourcing of biological resources, access and sharing of benefits, proper traceability of products derived from biodiversity, and awareness-raising of the value of nature. It is also important to improve income-earning opportunities for rural communities. It can also bring added dividends such as consolidating peacebuilding in post-conflict areas.

BioTrade covers the collection, production, transformation, and commercialization of goods and services originating from native biodiversity (species and ecosys- 
tems) in accordance with the criteria of sustainable environmental, social, and economic development.

The following sectors are involved in BioTrade activities: personal hygiene, pharmaceuticals/phyto-farm, food, fashion, protection of flora and fauna, handicrafts, textiles and natural fibers, sustainable tourism, forestry (UNCTAD 2016).

The main current BioTrade effects are noticed as follows (UNCTAD 2016, chapter 1):

- Sales in companies and associations of BioTrade beneficiaries achieved the level of EUR 4.3 billion, which was a significant increase from USD 40 million in 2003.

- Around 5 million beneficiaries worldwide.

- $83 \%$ of consumers expect companies to have a supply policy that respects biodiversity.

- 12,000 companies in over 70 countries have applied for the UN Global Compact, committing themselves to greater responsibility for the environment (and biodiversity).

- More and more companies reporting biodiversity in their annual reports; 36 of the 100 largest cosmetics companies and 60 of the top 100 food companies are involved in a business based on biodiversity.

- BioTrade has a share in almost all of the 17 Sustainable Development Goals ${ }^{4}$.

\section{The Circular Economy - the next step in the implementation of sustainable development strategies}

One of the weaknesses of modern industry is its high dependence on access to primary raw materials. Although many enterprises are introducing improvements and innovations that reduce the consumption of materials and energy per unit of production (e.g., per ton of product), this does not change the fact that the production of new products is still aiming for limited deposits of natural resources. The way out of the economy's dependence on primary raw materials may be a change in the source of raw materials for manufacturing processes. That is because the value and durability of products and materials in a circular economy are maintained for as long as possible. Resource utilization is minimized, and when the product reaches the end of its useful life, it is reused to create additional new value. It may generate substantial economic benefits, contributing to the creation of new production methods and new innovative products, growth, and job creation. Therefore, the circular economy model has been promoted for several years based on the 3Rs: reduce, reuse, and recycle, which means: 1. Produce new products - (product innovations) without generating waste - "Zero-Waste"

420 years of Bio-Trade, Connecting People, Planet and Markets, UNCTAD, Palais des Nations, 1211, Geneva 10, Switzerland.,2016/4, chapter, 1. http://unctad.org/en/PublicationsLibrary/ditcted2016d4 _en.pdf (accessed: 25.04.2018). 
2. However, if there is already waste, use it to create a new product, 3 . If 1 or 2 is not possible, direct the waste to recycling.

According to UNCTAD experts, traditional models of growth are becoming increasingly constrained. The Circular Economy offers lasting benefits in the form of material savings, new forms of employment, and reduced price volatility. At the same time, the international community has committed to change, as measured by the SDGs, especially in the industrial and innovation aspects of SDG 9, as well as sustainable consumption and production, embodied in SDG 12. Significant social gains can be realized from improving resource circularity in multiple sectors, such as in recycling and the reutilization of materials, energy efficiency, value-chain optimization, and in collaborative economy models such as in fast-growing space and vehicle sharing (UNCTAD, The Circular Economy). Circularity is already part of many lines of work within UNCTAD, such as activities on tackling fossil fuel and fisheries subsidies. Resource circularity cannot be promoted in international value chains just by promoting and enacting national rules. While companies have made strides in improving their social and environmental footprints, privatizing public policy through voluntary sustainability standards and Corporate Social Responsibility (CSR) falls short in this task. In a world where most trade happens in parts and components in highly globalized value chains, promoting global resource circularity goes through international rules and cooperation, as well as individuals and consumers empowered with education (UNCTAD, The Circular Economy).

\section{Implementing the principles of the circular economy in the European Union}

On 4 March 2019, the European Commission adopted a comprehensive report on the implementation of the Circular Economy Action Plan. The report presents the main achievements under the Action Plan and sketches out future challenges to shaping our economy and paving the way towards a climate-neutral, circular economy where pressure on natural and freshwater resources, as well as ecosystems, is minimized. The analysis served to assess to what extent EU policy tools addressing products are supporting circular, sustainable products. There are many policy tools covering all the different products on the EU market, and these tools together provide a great contribution to sustainability. They protect the environment and human health, make products more energy- and resource-efficient, and they empower consumers to choose better products. The analysis found that there is potential to further strengthen the policies, especially as concerns the circular design of products such as textiles and furniture. Also, more could be done to support consumers and circular sectors such as reuse and repair (EU Circular Economy Action Plan).

The above-mentioned report shows that the recycling rate of plastic packaging has almost doubled since 2005. Overall, the EU recycled around 55\% of all waste, exclud- 
ing major mineral waste, in 2016 , compared with $53 \%$ in 2010 . The recovery rate for construction and demolition waste reached $89 \%$, and the packaging waste recycling rate exceeded $67 \%$ compared with $64 \%$ in 2010 , while the municipal waste recycling rate was $46 \%$ in 2017 compared to $35 \%$ in 2007 . The recycling rate of electrical and electronic equipment waste (computers, televisions, refrigerators and mobile phones containing valuable materials that can be recovered) reached $41 \%$ (2016), compared with $28 \%$ in 2010 . Despite these high recycling rates, on average, only $12 \%$ of the material resources used in the EU in 2016 came from recycled and recovered materials, thus saving on the extraction of primary raw materials. This indicator, called the circular material use rate, measures the contribution of recycled materials to overall demand. The indicator is lower than recycling rates, which measure the share of waste that is recycled because some types of materials cannot be recycled, e.g., fossil fuels burned to produce energy, or biomass consumed as food or fodder (Record recycling rates and use of recycled materials in the EU 2019).

The diagnosis of the state of the implementation of the principles of the green and then circular economy shows that, in Europe, resources are being consumed, on average, twice as fast as our planet can reproduce them. Statistically, for every European in 2012, 14.2 tons of resources were used to manufacture both imported and manufactured products in the EU. The increasing demand for resources around the world means that European enterprises are starting to feel the increase in the costs of basic raw materials and materials, and they are struggling with shortages and price volatility, which weakens the competitiveness of the European economy. It was, therefore, necessary to take measures to reduce the overall consumption of resources and to introduce solutions that would improve the efficiency of their use. As part of the work on the EC proposal of 2015 regarding the Circular Economy, the European Parliament proposed setting a European resource efficiency increase target of at least 30\% by 2030 compared to 2014. The scale of this challenge is easier to assess knowing that, according to EU forecasts, the implementation of existing action scenarios could increase resource efficiency by 15\% between 2014 and 2030. The planned EU goal is not overly ambitious if you take into account the guidelines of the World Business Council for Sustainable Development to strive for a level of a 4- to 10-fold increase in resource efficiency by 2050 (Report From the Commission to the European Parliament... 2017; Commission Staff Working Document... 2019).

Key challenges at the stage of incorporating the project/company into the circular economy are (Eco-innovation Action Plan; see also Eco-Innovation Index):

- Eco-Design - The support and commitment of designers. The need to prioritize at the design stage issues such as minimizing the use of materials and energy, refraining from the use of hazardous substances, the possibility of repairing and reusing or recycling the item, and also using materials of biological origin. It is estimated that the introduction of the eco-design directive and, i.e., the Energy Label Directive, enabled the creation of 800,000 jobs and generated an additional EUR 55 billion in income for European enterprises. It also avoided the 
emission of a significant amount of greenhouse gases. European households have also benefited because they save an average of 432 euros a year in electricity bills (Komunikat Komisji 2016; see also: Bachorz 2017, pp. 25-31).

- The manufacturer's responsibility for the product after use. In $28 \mathrm{EU}$ countries, there are EPR (extended producer responsibility) schemes that extend the producer's responsibility for the product for the period after its use. In practice, this means that a business that has introduced a certain type of product to the market (e.g., a washing machine) is required to bear some or all of the costs associated with its development in the post-use phase. Charging the enterprise with this additional cost is intended to encourage it to introduce solutions that will make using the product cheaper in the post-use phase. The manufacturer can, for example, design more durable and repairable products with a lower weight. Thinking about the optimization of expenses related to waste management, it may also - at the design stage - choose materials that are more suitable for recycling and use substitutes for hazardous and problem substances.

It also became necessary to reduce enterprises' dependence on primary raw materials and to create a system for reuse and repair (cultural change). According to the assumptions of the circular economy, enterprises should base their production, firstly, on end-of-life products and components that have already been circulated, and secondly, on the use of secondary raw materials. The waste generated in plants should be treated as material that can be used on-site or easily transferred to another company for production purposes. An example of an industry in Europe that works largely on recyclable materials is the European paper industry. The signatories of the European declaration on paper recycling proved in 2017 that it is possible to use 59 million tons of waste paper as a secondary raw material, thereby bringing $71.5 \%$ of paper used in Europe to be recycled. The European glass industry, which, according to the European Glass Packaging Federation, achieved an average glass recycling rate of $74 \%$ in 2016 , can also boast good results. In the steel industry, a significant part of metal production also comes from recycling, e.g., in the case of copper, 50\% of this metal used in Europe comes from scrap recycling (Eco-innovation Action Plan; see also Eco-Innovation Index).

In December 2019, the European Commission presented a new strategy for the European Union under the name European New Deal for the coming years in order to strengthen the implementation of the main principles of the circular economy and achieve significant progress in reducing greenhouse gas emissions in Europe.

The European Green Deal is the new growth strategy of the EU. It will help us cut emissions while creating jobs (What is the European Green Deal? 2019). The EU proposes a green and inclusive transition to help improve people's well-being and secure a healthy planet for generations to come. The new strategy is about improving the well-being of people. Making Europe climate-neutral and protecting our natural habitat will be good for people, planet, and economy. No one will be left behind (What is the European Green Deal? 2019). 


\section{Main objectives of the new growth strategy of the EU are proposed as fol- lows:}

- Become climate neutral by 2050;

- Protect human life, animals, and plants by cutting pollution;

- Help companies become world leaders in clean products and technologies;

- Help ensure a just and inclusive transition.

The program was also based on the following opinions of most Europeans:

- $93 \%$ of Europeans see climate change as a serious problem,

- $93 \%$ of Europeans have taken at least one action to tackle climate change,

- $79 \%$ agree that taking action on climate change will lead to innovation (What is the European Green Deal? 2019).

The European Green Deal provides a road map with actions (Annex to the Communication from the Commission to the European Parliament...) to boost the efficient use of resources by moving to a clean, circular economy and stopping climate change, reversing biodiversity loss, and cutting pollution. It outlines the investments needed and financing tools available and explains how to ensure a just and inclusive transition. The European Green Deal covers all sectors of the economy, notably transport, energy, agriculture, buildings, and industries such as steel, cement, ICT, textiles, and chemicals (The European Green Deal sets out how to make Europe the first climate-neutral continent by 2050... 2019). Meeting the objectives of the European Green Deal will require significant investment. Achieving the current 2030 climate and energy targets is estimated to require $€ 260$ billion of additional annual investment, representing about $1.5 \%$ of 2018 GDP. This investment will need the mobilization of the public and private sectors. In early 2020, the Commission presented an investment plan for a sustainable Europe to help meet investment needs. At least $25 \%$ of the EU's long-term budget should be dedicated to climate action, and the European Investment Bank, Europe's Climate Bank, will provide further support. For the private sector to contribute to financing the green transition, the Commission will present a Green Financing Strategy in 2020. The European Union already has a strong track record in reducing its emissions of greenhouse gases while maintaining economic growth. Emissions in 2018 were 23\% lower than in 1990, while the Union's GDP grew by $61 \%$ in the same period. But more needs to be done. The EU, given its extensive experience, is leading the way in creating a green and inclusive economy (The European Green Deal sets out how to make Europe the first climate-neutral continent by 2050... 2019).

The EU's share in global emissions is declining, and we need to make sure now that our partners also take action. The Commission will enhance the enforcement of sustainability commitments in trade agreements. The EU is committed to (EU as a global leader 2019):

- Leading by example, through the European Green Deal.

- Using diplomacy, trade, and development cooperation to advance climate action.

- Setting standards for sustainable growth across global value chains. 
Under the new strategy, the EU is planning to enhance international cooperation:

- Work with Africa to bring climate and environment issues to the center of our relations.

- Engage with G20 countries who are responsible for $80 \%$ of global greenhouse gas emissions.

- Following the Poznan Summit, set up a Green Agenda for the Western Balkans, mirroring the Green Deal.

- Establish environment, energy, and climate partnerships with the Eastern Partnership and Southern Neighborhood.

- Build Green Alliances with partner countries and regions in Latin America, the Caribbean, Asia, and the Pacific. ${ }^{5}$

\section{Conclusions}

- Sustainable development focused on environmental protection and counteracting negative climate change have become the leading areas of interest for both the European Union and global organizations.

- This is due to the growing threats associated with soil, air, and water pollution on our planet as a result of the huge scale of waste collection and excessive dependence on depleting natural resources, including primarily primary raw materials.

- Research results point to the fact that Europeans alone, who make up only about $8 \%$ of the world population, consume mineral resources and use ecosystem services on average twice as fast as our planet can reproduce them.

- The contemporary model of economic development, based on continuous growth, may lead to the exhaustion of resources available at acceptable prices and destroy the biological foundations of life to such an extent that mankind will fight over drinking water and food, and will suffer from unpredictable, rapid climate changes.

- Many communities, enterprises, and local governments have taken steps to limit the consequences of such events that contribute to the emergence of many threats to life and health on Earth. The time has come to seek products and services that are, beginning at the design stage, intended for the longest possible life-cycle; to engage in transformations and the recycling of natural resources; and to exclude toxic materials and processes which generate harmful emissions.

- The idea of a circular economy, which can also be called a "closed-loop economy," i.e., one that produces minimum waste, and in which waste, if it is generated, becomes a raw material. The amount of real waste is constantly shrink-

5 Currently $40 \%$ of the world's public climate finance comes from the EU (EU as a global leader 2019). 
ing. The waste on our planet can be minimized by implementing responsible research to further the innovation principle, i.e., "reduce, reuse, and recycle." This means that each individual must reduce waste and, if he or she has generated any, reuse it or recycle it. This model can also bring significant economic benefits, contributing to new production methods and new innovative products, growth, and job creation.

- A helpful process in the pursuit of sustainable development and the circular economy is the progressing (although relatively slow) liberalization of trade in goods and services that are conducive to environmental protection and environmentally sound technologies at both European and global levels. It has contributed to increasing the share of developing countries and transition economies in access to technology and the market of goods and services conducive to environmental protection.

- UNCTAD initiatives related to the development of BioTrade (which created an opportunity especially for developing countries) should also be rated very positively because they build sustainable livelihoods, especially for rural communities and marginalized groups, and increase their activity for the development of biodiversity and sustainable use of natural resources. In addition, it should be emphasized that BioTrade has a share in almost all 17 sustainable development goals.

- The European Union is the world leader in environmentally friendly products and services within the sustainable development strategy, and the Circular Economy has become the next step in the implementation of sustainable development strategies. On 4 March 2019, the European Commission adopted a comprehensive report on the implementation of the Circular Economy Action Plan. The report presents the main achievements under the Action Plan and sketches out future challenges to shaping our economy and paving the way towards a climate-neutral, circular economy where pressure on natural and freshwater resources as well as ecosystems is minimized.

- Key challenges at the stage of incorporating the project/company into the circular economy are based inter alia on Eco-Design - the support and commitment of designers - and on the manufacturer's responsibility for the product after use in order to promote the reduction of the dependence of enterprises on primary raw materials and the creation of a system for reuse and repair.

- In December 2019, the European Commission presented a new growth strategy for the European Union under the name European New Deal for the coming years in order to strengthen the implementation of the main principles of the circular economy and achieve significant progress in reducing greenhouse gas emissions in Europe. 


\section{References}

20 years of Bio-Trade, Connecting People, Planet and Markets, UNCTAD, Palais des Nations, 1211, Geneva 10, Switzerland.,2016/4, chapter, 1. http://unctad.org/en/Pub licationsLibrary/ditcted2016d4_en.pdf (accessed: 25.04.2018).

Annex to the Communication from the Commission to the European Parliament, the European Council, the Council, the European Economic and Social Committee and the Committee of the Regions - The European Green Deal, Brussels, 11.12.2019 $\operatorname{COM}(2019) 640$ final.

Bachorz, M. (2017), Polska droga do gospodarki o obiegu zamkniętym. Opis sytuacji i rekomendacje, ISBN 978-83-947616-0-8 (Publikacja elektroniczna do ściągnięcia $\mathrm{w}$ formacie PDF, dostępna na stronie internetowej www.igoz.org w dziale Baza Wiedzy).

Commission Staff Working Document Sustainable Products in a Circular Economy - Towards an EU Product Policy Framework contributing to the Circular Economy (2019). https://ec.europa.eu/environment/circular-economy/pdf/sustainable_products_cir cular_economy.pdf (accessed: 8.10.2019).

Communication from the Commission to the European Parliament, the European Council, the Council, the European Economic and Social Committee and the Committee of the Regions, The European Green Deal, Brussels, 11.12.2019 COM(2019) 640 final. https://ec.europa.eu/info/sites/info/files/european-green-deal-communication _en.pdf (accessed: 20.12.2019).

Eco-innovation Action Plan. https:/ec.europa.eu/environment/ecoap/frontpage_en (accessed: 19.01.2020).

Eco-Innovation Index. https://ec.europa.eu/environment/ecoap/indicators/index_en (accessed: 18.01.2020).

Environmental Goods Agreement (EGA). https://www.wto.org/english/tratop_e/envir _e/ega_e.htm (accessed: 10.11.2019).

Environmental Goods Agreement news archive. https://www.wto.org/english/news_e/ar chive_e/ega_arc_e.htm (accessed: 10.11.2019).

Environmental Governance Update - August 2019 (2019) https://www.unenvironment .org/resources/report/environmental-governance-update-august-2019 (accessed: 16.10.2019).

Environmental rights and governance. https://www.unenvironment.org/explore-topics lenvironmental-rights-and-governance (accessed: 15.12.2019).

Environmental rights and governance overview. https://www.unenvironment.org/exp lore-topics/environmental-governance/about-environmental-governance/environ mental-governance (accessed: 5.12.2019).

EU as a global leader (2019). https://ec.europa.eu/commission/presscorner/detail/en/fs _19_6721 (accessed: 13.11.2019).

EU Circular Economy Action Plan. https://ec.europa.eu/environment/circular-econ omy/ (accessed: 5.10.2019).

Implementation of multilateral environmental agreements. https://www.unido.org/our -focus/safeguarding-environment/implementation-multilateral-environmental-ag reements (accessed: 5.11.2019). 
Komunikat Komisji (2016), Plan prac dotyczacy ekoprojektu na lata 2016-2019, Brussels, 30.11.2016; COM, 773 final. https://eur-lex.europa.eu/legal-content/PL/TXT /HTML/?uri=CELEX:52016DC0773\&from=PL (accessed: 20.10.2019).

Record recycling rates and use of recycled materials in the EU (2019). https://ec.europa .eu/eurostat/documents/2995521/9629294/8-04032019-BP-EN.pdf/295c2302-4ed1 -45b9-af86-96d1bbb7acb1 (accessed: 22.10.2019).

Report From the Commission to the European Parliament, the Council, the European Economic and Social Committee and the Committee of the Regions on the Implementation of the Circular Economy Action Plan (2017). https://ec.europa.eu/environment /circular-economy/implementation_report.pdf (accessed: 10.01.2020).

Sustainable Development Goals. https://www.unenvironment.org/explore-topics/sus tainable-development-goals (accessed: 23.01.2020).

The European Green Deal sets out how to make Europe the first climate-neutral continent by 2050, boosting the economy, improving people's health and quality of life, caring for nature, and leaving no one behind (2019). https://ec.europa.eu/commiss ion/presscorner/detail/en/ip_19_6691 (accessed: 15.12.2019).

The Food and Agriculture Organization, Environmental Safeguards. http://www.fao .org/investment-learning-platform/themes-and-tasks/environmental-social-safeg uards/environmental-safeguards/en/ (accessed: 24.01.2020).

Trade and environment. https://www.wto.org/english/tratop_e/envir_e/envir_e.htm (accessed: 12.11.2019).

UNCTAD (2016), 20 years of Bio-Trade, Connecting People, Planet and Markets, Geneva. http://unctad.org/en/PublicationsLibrary/ditcted2016d4_en.pdf (accessed: 12.11.2019).

UNCTAD, BioTrade. https:/unctad.org/en/Pages/DITC/Trade-and-Environment/Bi oTrade.aspx (accessed: 4.01.2020).

UNCTAD, The Circular Economy. https://unctad.org/en/Pages/DITC/Trade-and-En vironment/Circular-Economy.aspx (accessed: 2.12.2019).

UNESCO (2011), Launch of InforMEA - the United Nations Information Portal on Multilateral Environmental Agreements (MEAs). https://www.informea.org/en/launch -informea-\%E2\%80\%93-united-nations-information-portal-multilateral-environ mental-agreements-meas (accessed: 20.11.2019).

United Nations Environment Programme (2018), Trade in environmentally sound technologies: Implications for Developing Countries. http://wedocs.unep.org/bitstre am/handle/20.500.11822/27595/TradeEnvTech.pdf?sequence=1\&isAllowed=y (accessed: 28.10.2019).

What is the European Green Deal? (2019). https://ec.europa.eu/commission/presscor ner/detail/en/fs_19_6714 (accessed: 23.12.2019).

Wysokińska, Z. (2005), Foreign Trade in Environmental Products; The WTO Regulation and Environmental Programs, "Global Economy Journal", 5 (3). https://doi.org /10.2202/1524-5861.1076

Wysokińska, Z. (2009), The International Environmental Goods and Services Market: an Opportunity for Poland, "Polish Journal of Environmental Studies", 18 (5), pp. 941-948. 
Wysokińska, Z. (2011), Competitiveness of Selected New Members of the EU in the Environmental Products and Services Market, [in:] J. Blanco, H. Kheradmand, Climate Change. Socio-Economic Effects, In Tech. https://doi.org/10.5772/23597

Wysokińska, Z. (2017), Millennium Development Goals/UN and Sustainable Development Goals/UN as Instruments for Realising Sustainable Development Concept in the Global Economy, "Comparative Economic Research. Central and Eastern Europe", 20 (1), pp. 101-118. https://doi.org/10.1515/cer-2017-0006

\section{Streszczenie}

\section{Przegląd regulacji transnarodowych w dziedzinie ochrony środowiska i gospodarki cyrkularnej}

Celem artykułu jest zaprezentowanie przeglądu regulacji transnarodowych (globalnych i europejskich w dziedzinie ochrony środowiska i gospodarki cyrkularnej. W artykule omówione zostały regulacje zaproponowane w publikacjach i raportach przygotowanych przez takie organizacje globalne i Agendy ONZ jak: Program Ochrony Środowiska Narodów Zjednoczonych (UNEP); Konferencja ONZ do spraw Handlu i Rozwoju (UNCTAD), Organizacja Narodów Zjednoczonych do spraw Wyżywienia i Rolnictwa (FAO), jak również przez Światową Organizacja Handlu (WTO), oraz przez Komisję Europejską jako ciało wykonawcze Unii Europejskiej.

W odniesieniu do WTO regulacje te dotyczą efektów liberalizacji handlu towarami i usługami środowiskowymi oraz technologiami przyjaznymi środowisku.

Zrównoważony rozwój polega głównie na ochronie środowiska naturalnego oraz ograniczaniu w sektorze gospodarki nadmiernego uzależnienia od wyczerpujących się zasobów naturalnych w tym przede wszystkim od surowców pierwotnych. W tym znaczeniu proponowany jest od kilku lat nowy bardziej zasobooszczędny model rozwoju, bazujący na zasadach gospodarki cyrkularnej. W ramach tego modelu wykorzystanie zasobów jest zminimalizowane, a gdy produkt osiąga koniec okresu użytkowania, jest ponownie wykorzystywany do tworzenia dodatkowej nowej wartości. Może to generować znaczne korzyści ekonomiczne, przyczyniając się do tworzenia nowych metod produkcji i nowych innowacyjnych produktów, wzrostu oraz tworzenia miejsc pracy.

Słowa kluczowe: regulacje transnarodowe i europejskie, ochrona środowiska, gospodarka cyrkularna, organizacje globalne, Unia Europejska 